\title{
Keterpinggiran Kelompok Kesenian Cak Bedulu Dalam Seni Pertunjukan Pariwisata Bali
}

\author{
Ni Made Ruastiti \\ Fakultas Seni Pertunjukan, Institut Seni Indonesia Denpasar
}

nimaderuastiti@gmail.com

Artikel ini disusun berdasarkan hasil penelitian yang bertujuan untuk dapat mengetahui dan memahami keterpinggiran Tari Cak Bedulu dalam seni pertunjukan pariwisata Bali. Penelitian ini dilakukan karena dilatari adanya ketimpangan antara asumsi dan kenyataan yang terjadi di lapangan. Semestinya sebagai pelopor seni pertunjukan pariwisata Bali, kelompok kesenian ini paling sering ditampilkan dalam aktivitas kepariwisataan. Namun kenyataannya hal ini berbeda. Walaupun Cak Bedulu merupakan pelopor kesenian Cak untuk pariwisata Bali, kelompok kesenian ini justru mengalami keterpinggiran. Pertanyaannya: (1). Mengapakah kelompok kesenian ini mengalami keterpinggiran?; (2). bagaimanakah bentuk pertunjukannya?; dan (3). apakah implikasinya bagi masyarakat dan seni pertunjukan Bali?. Penelitian ini menggunakan metode kualitatif. Sumber data penelitian ini adalah pertunjukan Cak Bedulu, para pihak terkait, dan masyarakat di Desa Bedulu, Bali. Data yang dikumpulkan dengan teknik observasi, wawancara, FGD, dan studi pustakaan dianalisis dengan teori estetika, teori seni pertunjukan pariwisata, dan teori relasi kuasa pengetahuan. Hasil penelitian menunjukkan bahwa: (1). Kelompok kesenian Cak Bedulu mengalami keterpinggiran karena cara penyajiannya kini sudah tidak sesuai lagi dengan ideologi pasar, ideologi seni pertunjukan pariwisata, dan ideologi budaya masyarakat di Desa Bedulu; (2). Kesenian Cak Bedulu disajikan dalam bentuk sendratari dengan lakon Ramayana. Hal itu dapat dilihat dari cara penyajian, struktur pertunjukan, dan tata rias busana pertunjukannya; (3) Keterpinggiran Cak Bedulu secara tidak langsung berimplikasi pada hilangnya media berkesenian, hilangnya masukan finansial dari kegiatan berkesenian, dan hilangnya identitas budaya lokal.

Kata kunci: keterpinggiran, ideologi, estetika, cak bedulu, pariwisata bali.

\section{The Alienation Of Cak Bedulu Art Group In Balinese Tourism Performing Arts}

This article is written based on the research findings that aims to know and understand the alienation of Cak Bedulu Dance in Balinese tourism performing arts. This research was conducted due to the imbalance between assumptions and reality that occurred in the field. Supposedly, as a pioneer of Balinese tourism performing arts, this art group should be most often found in the tourism industry. However, although Cak Bedulu is one of the pioneers of art for Bali tourism, this art group actually experienced alienation. The question: (1) why do these art groups experience alienation? (2) what is the form of the performance? and (3) what are its implications for society and Balinese performing arts? This research applies qualitative method. The data source of this research is the performance of Cak Bedulu, related parties, and the society in Bedulu Village, Bali. The data collected by the techniques of observation, interview, focus group discussion, and library study were then analyzed by aesthetic theory, tourism performance theory, and the knowledge/power relation theory. The findings showed that: (1) Cak Bedulu arts groups experienced alienation because the way they were presented seemed no longer in line with the current market ideology, the ideology of tourism performing arts, and the cultural ideology of the local society, (2) The art groups of Bedulu Village present the Cak Bedulu performance in the form of drama dance with the Ramayana play. It can be seen from the way of presentation, costume and makeup, and the structure of the performance, and (3) The alienation of Cak Bedulu implies the loss of artistic media, financial input from artistic activities, and local cultural identity.

Keywords: alienation, ideology, aesthetics, cak bedulu, bali tourism

Proses Review : 1 - 18 April 2019, Dinyatakan Lolos: 22 April 2019 


\section{PENDAHULUAN}

Pulau Bali merupakan objek wisata yang sangat terkenal akan keunikan budayanya. Keunikan budaya Bali tercermin pada kehidupan masyarakatnya yang sebagian besar melibatkan seni pertunjukan. Hal itu dapat dilihat pada setiap acara-acara penting yang dilaksanakannya antara lain dalam konteks upacara, sosial, politik, hiburan, maupun untuk pariwisata. Namun dari sekian banyak jenis seni pertunjukan yang berkembang di daerah ini tampak seni pertunjukan untuk pariwisata paling pesat perkembangannya. Hal itu dapat dilihat dari banyaknya muncul kesenian baru dalam konteks pariwisata.

Salah satu daerah yang mengembangkan sektor pariwisatanya yaitu Daerah Gianyar. Berdasarkan monografi Kabupaten Gianyar, Kabupaten Gianyar memiliki beberapa faktor yang dapat menunjang pembangunan kepariwisataan. Faktor-faktor tersebut antara lain: (1) kebudayaan dan kehidupan masyarakat yang bersumber pada kebudayaan dan dijiwai oleh agama Hindu yang merupakan daya tarik kunjungan bagi wisatawan asing ke Kabupaten Gianyar; (2) keindahan alam, peninggalan sejarah dan purbakala sebagai objek wisata yang cukup mempesona; (3) tersedianya fasilitas transportasi dan telekomunikasi yang memadai; (4) fasilitas lain seperti hotel, home stay, dan restoran yang cukup banyak berkembang di sudut kota Gianyar; (5) produk pariwisata khususnya sekaa-sekaa seni pertunjukan pariwisata yang dimiliki oleh daerah Gianyar. Elemen-elemen daya tarik tersebut perlu untuk dilestarikan, ditumbuhkembangkan, dan dipertahankan keunikannya.

Kabupaten Gianyar dikenal sebagai daerah seni di Bali, karena banyak desa-desa di Gianyar memiliki citra seni tersendiri. Seperti Celuk yang terkenal sebagai pusat kerajinan emas dan perak, Singapadu sebagai pusat seni ukir batu paras, Batubulan dengan atraksi barong dan kris dance, Ubud sebagai pusat seni lukis, Sukawati sebagai pusat seni ukir kayu, Keramas sebagai pusat seni arja, Bona dikenal sebagai sentral kerajinan lontar, dan Bedulu yang merupakan tempat lahirnya kesenian Cak. Kesenian-kesenian tersebut berkembang seiring dengan kemajuan pariwisata. Namun tidak semua kesenian-kesenian di atas mengalami kemajuan ke arah positif karena dipengaruhi oleh berbagai faktor. Salah satu kesenian yang dimaksud adalah kesenian Cak Bedulu.

Cak Bedulu merupakan hasil karya seni pertunjukan yang digagas oleh Walter Spies pada tahun 1930-an. Cak ini terinspirasi dari koor pria dan wanita yang mengiringi tari Sanghyang Dedari. Cak Bedulu mengambil cerita dari epos Ramayana dan ditarikan oleh 100 sampai dengan 150 orang penari dengan hanya mengunakan bebuletan berwarna hitam. Musik pengiring tarian ini bersumber dari olah vokal para penarinya yang mengucapkan kata cak.., cak.., cak.., cak.
Munculnya Cak Bedulu diawali oleh kedatangan seorang seniman yang bernama Walter Spies dalam misinya membuat film dokumenter tentang kebudayaan Bali. Spies mendatangi beberapa desa di Bali yang masih kental akan kebudayaan leluhur dan kekhasan kesenian daerahnya. Saat mengunjungi Desa Bedulu, Walter Spies menyaksikan sebuah pertunjukan tari sakral yaitu Tari Sanghyang di Pura Goa Gajah. Tari Sanghyang dipercayai oleh masyarakat Desa Bedulu sebagai tari penolak bala. Tarian ini dipentaskan saat desa mengalami grubug (dilanda wabah penyakit dan banyak kematian secara mendadak). Pertunjukan tari sanghyang pada saat itu dikomandoi oleh seorang tokoh seni dari Desa Bedulu yang bernama I Wayan Limbak.

Ketika Walter Spies menonton Limbak berimprovisasi seperti Tari Baris tercetus gagasan untuk membuat sebuah pertunjukan sejenis yang dapat disajikan kepada para wisatawan. Karena tarian itu tidak dapat dipentaskan setiap waktu, Spies menyampaikan keinginannya dan disambut baik oleh I Wayan Limbak. Walter Spies memiliki gagasan untuk memodifikasi tarian Sanghyang tersebut menjadi sebuah tarian yang disuguhkan untuk wisatawan. Sehingga terciptalah sebuah seni pertunjukan pariwisata yang disebut dengan Cak Bedulu. Seiring waktu pertunjukan ini mulai digemari oleh pelaku, masyarakat pendukung, dan para wisatawan. Karena disamping menjadi ajang untuk berkesenian, Cak Bedulu juga dapat memberikan kontribusi dari aspek ekonomi bagi pelaku dan masyarakat secara umum (wawancara dengan Gusti Landra, 13 Januari 2017).

Kepopuleran Cak Bedulu pada saat itu sebagai daya tarik wisata pulau Bali kemudian diikuti oleh munculnya sekaa-sekaa Cak serupa di Bali seperti Cak Bona, Cak Uluwatu, dan lain-lain. Kesuksesan pementasan Cak Bedulu yang dipertunjukkan untuk pariwisata yang pertama kali ditampilkan di halaman Pura Goa Gajah dengan lakon "Kerebut Kumbakarna" itu seolah menjadi inspirasi bagi sekaa-sekaa Cak di Bali. Parawisatawan sangat tertarik dan antusias untuk menonton pertunjukan itu, dengan meningkatnya kunjungan wisatawan yang datang ke Desa Bedulu pertunjukan ini pun dijadikan sebagai pertunjukan regular di Goa Gajah dan Restoran Puri Suling (wawancara dengan A.A Oka Astawa, 13 Januari 2017). Namun, kepopuleran Cak Bedulu yang telah mendunia tersebut belakangan ini tampak semakin memudar, bahkan hilang dari ranah industri pariwisata Bali. Berbanding terbalik dengan keberadaan cak lain yang mengadopsi bentuk dari Cak Bedulu justru menjadi pertunjukan yang sangat digemari oleh para wisatawan. Sebagaimana diungkapkan Dibia (1999) bahwa Cak merupakan salah satu jenis seni pertunjukan pariwisata yang sangat popular dan diminati para wisatawan mancanegara.

Pada tahun 1960-an pementasan Cak Bedulu sering dipentaskan untuk menghibur para wisatawan di Pura Goa Gajah dan Restoran Puri Suling. Cak Bedulu pada saat itu 
di pentaskan secara regular. Tahun 1970-an Cak Bedulu dipentaskan secara regular di Stage Pura Samuan Tiga untuk menghibur parawisatawan yang datang ke Desa Bedulu. Pada tahun 1970-an Cak Bedulu juga sering dipentaskan di Hotel Hyatt bahkan sampai ke luar negeri seperti Belanda. Sampai akhirnya pada tahun 1990-an Cak Bedulu mulai jarang dipentaskan dan peminatnya semakin berkurang (wawancara dengan I Gusti Landra, 13 Januari 2017). Lama tidak dipentaskan akhirnya pada tahun 2013 pemerintah daerah berupaya untuk membangkitkan kembali Cak Bedulu karena Cak Bedulu dianggap sebagai warisan budaya yang adi luhung dengan mendatangkan seniman-seniman besar sebagai pembina Cak Bedulu. Setelah beberapa kali sekaa Cak Bedulu mendapat pembinaan akhirnya Cak Bedulu dipentaskan kembali pada saat Pesta Kesenian Bali (PKB). Namun upaya pembinaan yang dilakukan oleh pemerintah daerah belum dapat mengembalikan kejayaan Cak Bedulu.

Pada era global seperti sekarang ini, dengan meningkatnya kunjungan wisatawan dan tersedianya akomodasi pariwisata yang memadai seharusnya kesenian-kesenian pariwisata mengalami perkembangan namun, berbanding terbalik dengan kondisi Cak Bedulu yang semakin tenggelam. Padahal Desa Bedulu merupakan sebuah desa wisata yang memiliki banyak peningalan arkeologi dan tempat-tempat wisata, seperti Goa Gajah, Yeh Pulu, Museum Prubakala, Puri Bedulu, Pura Samuan Tiga, Tukaddari, dan memiliki stage untuk pementasan seni pertunjukan. Selain itu Desa Bedulu merupakan jalur artenatif untuk menuju tempat wisata lainnya seperti ke tampaksiring. Namun hal itu tidak berpengaruh terhadap keberadaan Cak Bedulu, tetap saja Cak Bedulu ini tidak terlihat dipermukaan. Ibaratkan Ayam yang mati di lumbung padi. Berbeda dengan keberadaan Cak lainya, yang bahkan dapat memberikan masyarakat pendukungnya kontribusi.

Berkembangnya industri pariwisata banyak mempengaruhi perkembangan seni pertunjukan di Bali. Hal itu dapat dilihat dari banyaknya bermunculan seni pertunjukan baru yang pada awalnya hanya ada seni pertunjukan upacara yang sifatnya sakral saja. Spillane (1987) mengungkapkan bahwa industri pariwisata secara tidak langsung dapat memberikan peran penting dalam perkembangan budaya. Interaksi antara masyarakat Bali dengan pariwisata tanpa disadari melahirkan perubahan-perubahan pada berbagai aspek kehidupan masyarakatnya. Sebagaimana diungkapkan Ruastiti (2010) bahwa perubahan kebudayaan masyarakat Bali dapat dilihat dari sikap dan orientasi masyarakatnya dalam mengembangkan potensi dan sumber daya yang dimiliki untuk kepentingan pariwisata.

Perkembangan pariwisata di Bali berdasarkan Perda Nomor 3 Tahun 1991 tentang Pariwisata Budaya menjelaskan bahwa kebudayaan daerah sebagai bagian dari kebudayaan nasional, merupakan potensi dasar yang dominan bagi pengembangan pariwisata yang harus dibina dan ditum- buh kembangkan, serta dapat dipertahankan nilai dan ciri-cirinya yang khas dalam kegiatan-kegiatan kepariwisataan dan setiap pengembangan pariwisata di Bali mesti bernuansakan budaya Bali. Berdasarkan kebijakan tersebut industri pariwisata Bali mengalami kemajuan yang sangat pesat.

Pariwisata sebagai suatu sistem, terdiri atas komponen-komponen daya tarik (attraction), aksesibilitas, dan ameneties. Dalam konteks ini lokasi dan akomodasi pariwisata merupakan bagian terpenting yang harus di jaga dan dikembangkan. Salah satu daerah yang mengembangkan sektor pariwisatanya yaitu Daerah Gianyar. Kabupaten Gianyar dikenal sebagai daerah seni di Bali. Hal itu dapat dilihat dari terampilnya masyarakat setempat dalam berkesenian. Seperti Celuk yang terkenal sebagai pusat kerajinan emas dan perak, Singapadu sebagai pusat seni ukir batu paras, Batubulan dengan atraksi barong dan kris dance, Ubud sebagai pusat seni lukis, Sukawati sebagai pusat seni ukir kayu, Keramas sebagai pusat seni arja, Bona dikenal sebagai sentral kerajinan lontar, dan Bedulu yang merupakan tempat lahirnya kesenian Cak. Kesenian-kesenian tersebut berkembang pesat seiring dengan kemajuan pariwisata. Namun demikian, tidak semua kesenian-kesenian di atas mengalami kemajuan. Salah satu kesenian yang mengalami keterpinggiran adalah kesenian Cak Bedulu.

Cak Bedulu merupakan hasil karya seni pertunjukan yang digagas oleh Walter Spies pada tahun 1930-an. Cak ini terinspirasi dari koor pria dan wanita yang mengiringi tari Sanghyang Dedari. Cak Bedulu mengambil cerita dari epos Ramayana dan ditarikan oleh 100 sampai dengan 150 orang penari dengan hanya mengunakan bebuletan berwarna hitam. Musik pengiring tarian ini bersumber dari olah vokal para penarinya yang mengucapkan kata cak.., cak.., cak.., cak.

Cak Bedulu pertamakali muncul atas gagasan seorang pelukis Barat bernama Walter Spies yang sedanng membuat film dokumenter tentang kebudayaan Bali. Spies mendatangi beberapa desa di Bali yang masih kental akan kebudayaan leluhur dan kekhasan kesenian daerahnya. Saat mengunjungi Desa Bedulu, Walter Spies menyaksikan sebuah pertunjukan tari sakral yaitu Tari Sanghyang di Pura Goa Gajah. Tari Sanghyang diyakini masyarakat Desa Bedulu sebagai tari penolak bala. Tarian tersebut dipentaskan saat desa mengalami grubug (dilanda wabah penyakit dan banyak kematian secara mendadak). Pertunjukan tari Sanghyang pada saat itu dipimpin oleh seorang seniman dari Desa Bedulu bernama I Wayan Limbak. Ketika Walter Spies menonton Limbak menari berimprovisasi seperti Tari Baris tercetus gagasan untuk membuat sebuah pertunjukan sejenis yang dapat disajikan kepada para wisatawan. Karena tarian itu tidak dapat dipentaskan setiap waktu, Walter Spies memiliki gagasan untuk membuat tari Sanghyang serupa untuk disajikan kepada wisatawan. Tercip- 
talah sebuah seni pertunjukan pariwisata yang disebut Cak Bedulu. Seiring waktu pertunjukan Cak Bedulu sangat digemari masyarakat setempat maupun wisatawan. Karena disamping menjadi media untuk berkesenian, Cak Bedulu ternyata juga dapat memberikan kontribusi ekonomi bagi pelaku dan masyarakat umum lainnya (wawancara dengan Gusti Landra, 13 Januari 2017).

Kepopuleran Cak Bedulu pada saat itu sebagai daya tarik wisata pulau Bali kemudian diikuti oleh munculnya sekaa-sekaa Cak serupa di Bali seperti Cak Bona, Cak Uluwatu, dan lain-lain. Kesuksesan pementasan Cak Bedulu yang dipertunjukkan untuk pariwisata yang pertama kali ditampilkan di halaman Pura Goa Gajah dengan lakon "Kerebut Kumbakarna" itu seolah menjadi inspirasi bagi sekaa-sekaa Cak di Bali. Parawisatawan sangat tertarik dan antusias untuk menonton pertunjukan itu, dengan meningkatnya kunjungan wisatawan yang datang ke Desa Bedulu pertunjukan ini pun dijadikan sebagai pertunjukan regular di Goa Gajah dan Restoran Puri Suling (wawancara dengan A.A Oka Astawa, 13 Januari 2017). Namun, kepopuleran Cak Bedulu yang telah mendunia tersebut belakangan ini tampak semakin memudar, bahkan hilang dari ranah industri pariwisata Bali. Berbanding terbalik dengan keberadaan cak lain yang mengadopsi bentuk dari Cak Bedulu justru menjadi pertunjukan yang sangat digemari oleh wisatawan.

Lama tidak pentas, akhirnya pada tahun 2013 pemerintah daerah berupaya untuk membangkitkan kembali Cak Bedulu karena Cak tersebut dianggap sebagai warisan budaya yang adi luhung. Setelah beberapa kali sekaa Cak Bedulu mendapat pembinaan akhirnya Cak Bedulu dipentaskan kembali pada saat Pesta Kesenian Bali (PKB). Upaya pembinaan yang dilakukan oleh pemerintah daerah belum dapat mengembalikan kejayaan Cak Bedulu. Padahal dengan meningkatnya kunjungan wisatawan ke Bali dan tersedianya akomodasi pariwisata yang memadai seharusnya Cak Bedulu sebagai seni pertunjukan pariwisata berkembang pesat. Tetapi kenyataannya tidak demikian. Padahal Desa Bedulu merupakan sebuah desa wisata yang ramai dikunjungi wisatawab karena di desa tersebut banyak terdapat objek wisata seperti Goa Gajah, Yeh Pulu, Museum Purbakala, Puri Bedulu, Pura Samuan Tiga, Tukaddari, dan memiliki stage untuk pementasan seni pertunjukan. Selain itu Desa Bedulu merupakan jalur artenatif untuk menuju tempat wisata lainnya seperti ke tampaksiring, dan lain sebagainya. Namun hal itu tidak berpengaruh terhadap keberadaan Cak Bedulu. Tetap saja Cak Bedulu tidak terlihat dalam aktivitas kepariwisataan yang marak menampilkan kesenian Cak. Kondisi Cak Bedulu seperti ayam mati di lumbung padi. Berbeda halnya dengan sekaa-sekaa Cak lainya. Mereka tetap sibuk dan semarak menghiasi acara-acara kepariwisataan di Bali. Hal itu menimbulkan pertanyaan: (1). Mengapakah Cak Bedulu mengalami keterpinggiran?; (2). Bagaimanakah bentuk pertunjukannya?; Apakah implikasinya bagi masyarakat dan seni pertunjukan Bali?

\section{METODE PENELITIAN}

Penelitian ini menggunakan metode penelitian kualitatif. Sumber data penelitian ini adalah kelompok kesenian Cak Bedulu, para pihak terkait, masyarakat setempat, ditunjuang literatur dan hasil-hasil penelitian yang telah dihasailkan para peneliti sebelumnya. Data primer, berupa informasi dan hal-hal terkait diperoleh langsung melalui wawancara dengan para informan terkait yang dipilih berdasarkan teknik purposif sampling. Beberapa informan yang dimaksud antara lain para penari $\mathrm{Cak}$, pengurus, pelatih, dan masyarakat di Desa Bedulu yang mengetahui keberadaan kelompok kesenian tersebut.

Tahapan observasi mulai dilakukan sebelum wawancara dilakukan dengan para informan terpilih. Untuk menyimak fenomena ini secara mendalam dilakukan wawancara dengan para informan terkait antara lain dengan pelatih, ketua kelompok kesenian, para tokoh desa, penari, tersebut. Wawancara dilakukan setelah bertemu langsung dengan kepala desa selaku informan pangkal. Berdasarkan informasi yang diberikan oleh kepala desa dilakukan wawancara mendalam dengan para pihak terkait dan seterusnya hingga informasi yang diperoleh dianggap cukup. Penambahan informan juga dilakukan untuk melengkapi data yang masih kurang dengan menggunakan teknik snowball sampling.

Untuk melengkapi data penelitian ini dilakukan studi kepustakaan yang dilakukan dengan menelusuri hasil-hasil penelitian sejenis yang telah dihasilkan oleh para peneliti sebelumnya. Seluruh data yang telah dikumpulkan kemudian dianalisis secara kritis dengan menggunakan teori seni pertunjukan pariwisata, teori praktik, dan teori relasi kuasa pengetahuan.

\section{HASIL PENELITIAN DAN PEMBAHASAN}

\section{Keterpinggiran Cak Bedulu}

Cak Bedulu kini telah mengalami keterpinggiran. Hal itu disebabkan oleh beberapa faktor baik dari seniman pendukungnya, pasar, maupun dari lingkungan masyarakatnya. Tidak dapat dipungkiri bahwa banyak kelompok-kelompok kesenian tradisional yang mengalami keterpingiran akibat dari modernisasi dan arus globalisasi. Tekanan dari pengaruh luar terhadap kesenian tradisional dapat dilihat dari pengaruh berbagai karya-karya kesenian populer dan juga karya-karya kesenian yang lebih modern dibandingkan kesenian tradisional yang disajikan secara konvensional. Kurangya kepedulian generasi muda terhadap eksistensi kesenian tradisional yang dimilikinya, padahal seni tradisional itu merupakan kebudayaan yang harus dijungjungtinggi sebagai identitas mereka diabaikan. Generasi muda banyak yang lebih memilih untuk mengikuti arus perkembangan jaman, sehingga mereka lebih 
tertarik terhadap hal-hal yang bersifat modern dan mulai meningalkan tradisi yang sudah melekat pada masyarakat. Berdasarkan kenyataan yang ada selama ini bakat sangat menentukan seseorang untuk melangkah dan memperdalam suatu ilmu. Tetapi hal itu saja masih belum cukup karena harus pula ada kemauan yang kuat yang mendasari pemilihan bidang ilmu tersebut, tanpa adanya suatu kemauan meskipun dengan bakat yang ada masih akan terasa adanya kekurangan dalam suatu proses pendalaman ilmu. Bakat merupakan potensi yang dimiliki oleh seseorang sebagai bawaan sejak lahir. Sukardi dalam (Sunaryo, 2004) mendefinisikan bakat sebagai suatu kondisi atau kualitas yang dimiliki oleh individu yang memungkinkan dirinya dapat berkembang dimasa yang akan datang. Bingham dalam Bennet (1952) menyatakan bahwa bakat merupakan kondisi atau rangkaian karakteristik yang dipandang sebagai gejala kemampuan individu untuk memperoleh pengetahuan, keterampilan, atau serangkaian respon melalui latihan-latihan. Suganda (2002) berpendapat bahwa bakat adalah benih atau bibit dari suatu sifat tertentu yang akan tampak secara jelas dan nyata jika diasah dan mendapatkan kesempatan untuk berkembang. Sedangkan Utami Munandar (1987) mengemukakan bahwa bakat dapat diartikan sebagai kemampuan bawaan, sebagai potensi yang masih perlu dikembangkan dan dilatih agar dapat terwujud. Dengan kata lain bakat merupakan hasil interaksi antara hereditas dan pendidikan. Bakat dapat berkembang dengan baik bila didorong oleh 2 faktor yaitu faktor individual dan faktor lingkungan.

Dorongan dari individu sangat mempengaruhi pengembangan bakat. Misalnya, individu itu tidak berminat untuk megembangkan bakat yang dimiliki atau kurang termotivasi untuk mencapai prestasi tinggi, atau mungkin pula mempunyai kesulitan masalah pribadi sehingga ia mengalami hambatan dalam pengembangan diri dan berprestasi sesuai dengan bakatnya. Lingkungan individu misalnya orang tuanya kurang mampu untuk menyediakan kesempatan dan sarana pendidikan yang ia butuhkan atau keadaan orang tua dengan kondisi ekonomi yang cukup tinggi tetapi kurang memberi perhatian terhadap pendidikan individu. Pembentukan karakter berkesenian juga sangat ditentukan oleh tradisi lingkungan keluarga. Kebiasaan orang tua memberikan apresiasi terhadap berbagai bentuk kesenian sejak usia dini melalui sistem oral, imaginatif, dan imitatif merupakan akumulasi pembentukan karakter anak sejak balita. Seperti halnya berdongeng sebelum tidurdan menyanyikan lagu-lagu dan menggerakkan anggota badan anak sesungguhnya suatu hal yang tidak dapat dilupakan oleh anak dan menjadi kenangan masa kecilnya. Jika kemudian ia tumbuh menjadi seorang seniman yang berbakat, tentu di samping secara biologis dari faktor genetika alamiah, tampaknya proses pembentukan watak sejak usia dini melalui peran lingkungan keluarga dan lingkungan sekitar juga tak dapat diabaikan.
Masyarakat Bedulu adalah masyarakat yang mayoritas penduduknya sebagai pedagang. Kehidupan keseharian masyarakatnya disibukan dengan kegiatan berdagang. Disamping sebagai pedagang masyarakatnya juga banyak berprofesi sebagai buruh tani, wiraswasta, pegawai negeri sipil, dan lain sebagainya. Melihat kondisi seperti itu hampir setiap hari baik orang tua, remaja, maupun anak-anak selalu disibukan oleh rutinitas keseharian mereka masing-masing. Kemampuan dan bakat yang dimiliki dalam bidang seni hanya digunakan sebagai hiburan belaka dan untuk mengisi waktu luang. Ketertarikan masyarakat tehadap kesenian yang ada di desanya sangatlah minim apalagi untuk melestarikan kesenian tersebut. Seperti dibahas sebelumnya bahwa bakat dan kemampuan seseorang sangat dipengaruhi oleh faktor lingkungan. Kondisi lingkungan yang mayoritas penduduknya berkecimpung dalam bidang seni misalnya, secara otomatis disana akan tumbuh kesenian-kesenian yang mencirikan kekhasan masyarakat tersebut.

Di Desa Bedulu yang mayoritas penduduknya berprofesi sebagai pedagang kiranya cukup beralasan bahwa penduduk di desa tersebut sering disibukan dengan kegiatan sehari-harinya sebagai pedagang sehingga mereka tidak memiliki banyak waktu untuk memperhatikan dan mengembangkan bakat seni yang dimiliki oleh anak-anak mereka.Hal itu menandakan bahwa di samping faktor bakat alamiah yang dibawa sejak lahir dan faktor pendidikan, proses pelatihan juga sangat menentukan keberhasilan seseorang untuk menjadi seorang seniman.Latihan adalah kunci dari keberhasilan. Latihan disini bukan saja dari segi kuantitasnya tetapi juga dari segi motivasi yang menggerakkan setiap usaha yang kelihatan secara fisik. Faktor lingkungan juga memiliki berpengaruh penting. Lingkungan disini tentu dalam arti yang sangat luas termasuk manusia, fasilitas, biaya, dan kondisi sosial lainnya yang turut berperan dalam usaha pengembangan bakat dan minat. Satu yang tidak kalah penting yaitu perlu memahami hambatan-hambatan pengembangan bakat dan cara mengatasinya.

Jakob Sumardjo (2000) menjelaskan bahwa kreativitas muncul saat obsensi timbul dalam diri manusia kreatif. Obsensi muncul kalau yang diinginkan individu tak sesuai dengan kenyataan di luar dirinya.Manusia kreatif bukanlah manusia kosong mental.Manusia kreatif adalah manusia yang memiliki gambaran suatu sikap baru, pandangan baru, konsep baru, sesuatu yang sifatnya esensial.Semua merupakan gambaran invidual bertabrakan dengan kenyataan yang tidak sesuai.Maka terjadilah kondisi gelisah, tidak nyaman, tidak sesuai, tidak senang. Ketenangan jiwa akan tercapai apabila ada kesesuian, di sinilah orang yang kreatif menemukan apa yang dicarinya, disingikan secara intuisi, nalar dan rasa indrawi. 
Proses kreatif dimulai dari dalam diri manusia berupa pikiran, perasaan atau imajinasi kreatif manusia kemudian dituangkan menggunakan media dan teknik tertentu, sehingga melahirkan karya-karya kreatif. Utami Munandar menyatakan bahwa secara luas kreativitas bisa berarti sebagai potensi kreatif, proses kreatif dan produk kreatif. Proses kreativitas melalui kegiatan seni adalah jalan sebaik-baiknya yang dapat dilakukan sebab melakukan kegiatan seni berarti terjadi suatu proses kreatif(Kusumastuti, 1990). Dorongan kreatifitas berasal dari tradisi itu sendiri atau masyarakat lingkungannya.Setiap seniman dilahirkan dalam masyarakat tertentu dengan tradisi tertentu.Tradisi seni telah ada sebelum adanya seniman.Setiap karya merupakan kekayaan tradisi seni atau masyarakat pada mulanya juga karya yang kreatif pada zamannya.Seniman kreatif adalah seniman yang peka terhadap lingkungan hidupnya. Baik tradisi budaya maupun kekayaan faktual lingkungan (Sumardjo, 2000).

Sifat kreatif seniman muncul karena dorongan naluri untuk berkarya sebagai luapan emosi yang meledak-ledak, sedangkan dorongan untuk maju merupakan etos berkesenian yang mendorong untuk menghasilkan sebuah karya yang bermutu.Kreatifitas muncul tidak hanya dorongan perasaan tetapi melibatkan kebenaran intuitif.Jadi kreatifitas selalu dimulai dengan ketidakpuasan batin.Sebagai seorang seniman yang kreatif sangat terdorong oleh berbagi situasi dilapangan.Keadaan dilapangan atau disekitarnya mampu memberikannya sebuah inspirasi untuk berkarya.Memang sangat jarang ditemukan seorang seniman yang berkarya secara idealisme. Artinya tanpa ada peluang atau pesanan ia tetap berkarya dan berkarya, namun pada umumnya seniman berkarya apabila ada permintaan, pesanan, atau ditugaskan oleh atasan.

Koentjaraningrat (1987:256) mengatakan bahwa sikap dalam mengembangkan penemuan-penemuan baru atau menciptakan karya baru adalah kesadaran para individu akan kekurangan dalam kebudayaan, dan sistem perangsangan dari aktivitas pencipta dalam masyarakat. Seiring dengan hal tersebut Kodiran (1999:534) mengatakan bahwa masyarakat senantiasa ingin menyesuaikan diri terhadap perubahan lingkungan yang disebabkan oleh faktor endogen (pengaruh dari dalam) dan faktor eksogen (pengaruh dari luar). Berdasarkan atas pemahaman tersebut, masyarakat selalu menghendaki adanya suatu nuansa baru, tidak puas dengan apa saja yang telah ada. Lahirnya sebuah karyakarya kreasi baru dan kontemporer tidak terlepas dari adanya kedua faktor tersebut, yang secara konseptual telah menunjukan sebuah fenomena baru dalam tata penyajiannya.Adanya kesesuaian ide baik dari faktor endogen dan eksogen ini telah memunculkan karakteristik karya baru yang lebih akulturatif.

Seniman yang kreatif harus tanggap akan perubahan yang terjadi dalam lingkungannya, mereka akan mampu membaca kejanggalan dan ketidakseimbangan unsur yang terja- di dalam kehidupan masyarakat. Boleh jadi suatu budaya atau sikap hidup masyarakat sudah tidak sesuai lagi dengan suatu kenyataan faktual yang ada atau seniman sudah tidak puas lagi akan tradisi budayanya. Sehingga mereka melakukan kreativitas yaitu membuat sesuatu yang baru sesuai dengan kebutuhan kehidupan budaya yang berkembang.

Terkait dengan Cak Bedulu yang kurang mendapat respon dan apresiasi dari pasar, disebabkan kurang adanya pembaharuan, baik dalam bentuk dan struktur pementasannya. Tidak ada inbovasi baru yang dimasukkan kedalam pertunjukan Cak Bedulu yang lebih inovatif. Seniman pendukungnya kurang kreatif dan jeli dalam melihat peluang-peluang kedepan. Untuk mendapatkan apresiasi yang baik dari masyarakat seharusnya dilakukan pembaharuan-pembaharuan dalam pertunjukan tersebut yang sedikit tidaknya sesuai dengan keadaan masyarakat sekarang ini. Masyarakat tentu tidak bisa menerima begitu saja fenomena dimana kesenian tradisinya menjadi beku, terpinggirkan, atau tenggelam oleh jaman. Karena itu setiap seniman harus berupaya untuk melakukan inovasi-inovasi baru untuk menciptakan sebuah karya. Para seniman secara sadar dan kreatif dan selektif memberikan ide-ide yang segar guna member nafas baru yang dapat mendekatkan kesenian mereka dengan konteks kehidupan masyarakat masa kini. Kesadaran seperti itu setidaknya menjadi landasan untuk berkarya.

\section{Distribusi}

Kepariwisataan merupakan suatu industri yang kompleks, maka organisasi-organisasi pariwisata harus ditata, diorganisasikan, dan dijalankan menurut konsep-konsep manajemen dan pemasaran. Manajemen meliputi 5 unsur pokok yaitu: (a). Pengorganisasian; (b). Perencanaan; (c). Motivasi; (d). Penempatan personal dan penggeraknya; (e). Koordinasi dan pengawasan. Berbagai fungsi manajemen ini dapat diterapkan pada setiap sektor bidang perindustrian pariwisata budaya. Tata kelola objek pariwisata haruslah pengelolaan yang berkelanjutan untuk menjadikan objek pariwisata tersebut menarik bagi wisatawan. Pengelolaan berkelanjutan adalah pengelolaan yang dapat memenuhi kebutuhan dan aspirasi manusia saat ini, tanpa mengorbankan potensi pemenuhan kebutuhan dan aspirasi manusia di masa mendatang. Pada kondisi ekologis tersebut seharusnya ditambahkan faktor-faktor sosial yang berpengaruh langsung pada berkelanjutannya interaksi antara kelompok masyarakat dan lingkungan fisiknya. Objek dan daya tarik wisata umumnya terdiri atas hayati dan non hayati, dimana masing-masing memerlukan pengelolaan sesuai dengan kualitas dan kuantitasnya pengelolaan obyek dan daya tarik wisata harus memperhitungkan berbagai sumber daya wisatanya secara berdaya guna agar tercapainya sasaran yang diinginkan. Setelah unsur manajemen tata kelola pariwisata diterapkan dengan baik selanjutnya bagaimana mengatur fungsi pemasaran terpadu dalam pariwisata. Pemasaran bisanya ditafsirkan dengan 
sekelompok aktivitas yang dilakukan untuk merumuskan pasar, mempelajari dan menganalisa kebutuhan dan selera konsumen, meninjau dan menyesuaikan kembali produksi sebagaimana mestinya, mengembangkan alat atau cara untuk mendekatkan kebutuhan konsumen pada produksi dan bahkan menciptakan kebutuhan-kebutuhan itu. Pemasaran juga bertujuan untuk memuaskan pelanggan melalui penyempurnaan produk. Pada awalnya pemasaran dilakukan setelah melakukan produksi tanpa memikirkan kebutuhan-kebutuhan pelanggan sehingga produk yang diproduksi belum tentu akan menguasai pasaran.

Sebuah organisasi harus mampu mencari informasi tentang kebutuhan-kebutuhan, harapan-harapan, sikap, tingkah laku, kesukaan, dan hal yang tidak disukai pada saat merumuskan dan mengembangkan komponen produk wisata. Karena itu konsep pemasaran ini harus diartikan sebagai suatu reorientasi kebijakan usaha dan suatu pembenahan total dalam pemikiran-pemikiran dasar dan penerapannya dalam manajemen organisasi atau badan usaha. Hal ini membantu organisasi dan badan usaha pariwisata untuk menetapkan suatu sistem komunikasi yang efektif dan konsisten.

Pengelolaan kepariwisataan pada hakekatnya sama dengan mengelola sebuah perusahaan dengan produk tertentu. Usaha ini melibatkan juga penjual yang terdiri atas pemerintah, investor, dan agen-agen di sektor kepariwisataan seperti pengusaha hotel, restoran, biro perjalanan, dan lain-lain, sementara itu sebagai pelanggan atau pembeli adalah para wisatawan itu sendiri baik itu yang berasal dari mancanegara maupun domestik. Pariwisata tanpa promosi adalah sia-sia dan untuk meningkatkan penjualan kepariwisataannya suatu daerah harus melakukan promosi yang gencar untuk menarik sebanyak-banyaknya turis mancanegara maupun domestik sehingga tujuan dari pariwisata dalam meningkatkan pendapatan daerah dan taraf hidup masyarakat dapat terwujud.

Kaitannya dengan tata kelola pertunjukan Cak Bedulu yaitu unsur manajemen, pemasaran, dan promosi tidak berjalan dengan maksimal. Sekaa Cak Bedulu tidak memiliki struktur organisasi yang baik dan organisasi tidak dapat berfungsi dengan efektif. Tingkat partisipasi masyarakat pendukung Cak Bedulu sudah sangat menurun. Masyarakat lebih memilih mencari suatu pekerjaan yang lebih menjanjikan untuk menyambung kehidupan. Minimnya pemasaran dan promosi ke publik semakin menenggelamkan eksistensi Cak Bedulu. Tidak banyak wisatawan yang mengetahui akan keberadaan kesenian ini. Pengembangan strategi pasar sangat perlu dilakukan agar bisa bersaing dengan para kompetitor.

Untuk membangkitkan kembali Cak Bedulu harus didukung oleh berbagai pihak dan sektor yang terkait dengan kepariwisataan. Motivasi wisatawan untuk mengun- jungi suatu tempat tujuan wisata adalah untuk memenuhi atau memuaskan beberapa kebutuhan atau permintaan. Di Desa Bedulu memiliki banyak objek wisata sedangkan Cak Bedulu merupakan pertunjukan ikonik dari Desa Bedulu. Seharusnya Cak Bedulu bisa dijadikan sebagai sebuah daya tarik dan hiburan bagi wisatawan yang berkunjung di objek wisata yang berada di Desa Bedulu seperti objek wisata Goa Gajah. Tetapi pada kenyataannya peluang tersebut tidak dimanfaatkan dengan baik oleh masyarakat desa sebagai pengelola objek wisata. Dari segi fasilitas pendukung Desa Bedulu masih kalah jika dibandingkan dengan desa-desa wisata lainnya. Sangat dibutuhkan peran pemerintah, masyarakat, investor, dan agen pariwisata untuk mengembangkan potensi wisata yang ada di Desa Bedulu sehingga produk kesenian pariwisata yang ada di Desa Bedulu dapat di pasarkan dengan baik.

\section{Konsumsi}

Pertunjukan yang diiringi olah vokal tersebut menampilkan cerita Ramayana dengan lakon Subali Sugriwa. Para penari Cak yang berjumlah 40-60 orang penari tersebut seluruhnya berasal dari Desa Bedulu yang terdiri atas lima Banjar, yaitu dari Banjar Goa, Banjar Tengah, Banjar Batu Lumbang, Banjar Lebah, Banjar Marga Bingung. Dikembangkannya Desa Bedulu sebagai desa wisata Cak Bedulu dijadikan sebagai sebuah pertunjukan pariwisata. Hal itu disambut baik oleh masyarakat Desa Bedulu, sehingga terbentuklah sebuah sekaa Cak Yang bernama Sekaa Cak Mekar Sari. Ketika itu berbagai komponen pembentuk tari adalah warga masyarakat. Pola konsumsi pertunjukan Cak sejak awal muncul, berkembang hingga mengalami marginalisasi dikomsumsi dari daerah setempat. Baik penari maupun maupun peralatan tari diperoleh dari masyarakat setempat. Dengan adanya minat wisatawan untuk menonton pertunjukan Cak tersebut masyarakat setempat mempertunjukan kesenian itu untuk pariwisata. Warga di Desa Bedulu akhirnya menata pertunjukan Cak tersebut agar sesuai dengan keinginan wisatawan yang datang menonton pertunjukan itu.

Seni pertunjukan merupakan salah satu unsur kebudayaan hasil dari aktivitas manusia. Sebagai hasil dari kebudayaan, perkembangan unsur kebudayaan itu sesuai dengan situasi, kondisi lingkungan alam tempat masyarakat tersebut berada. Seni pertunjukan sebagai salah satu unsur kebudayaan dipengaruhi oleh dua faktor yakni dari dalam kelompok masyarakat itu sendiri (internal) dan dari luar (eksternal) masyarakat yang bersangkutan. Terkait dengan itu Soedarsono (2002:1) menyatakan bahwa penyebab hidup-matinya suatu seni pertunjukan ada bermacam-macam. Ada yang disebabkan oleh ekonomi, selera pasar (penonton), politik, maupun karena tidak mampu bersaing dengan seni-seni pertunjukan lainnya. Namun ada juga seni pertunjukan yang bisa berkembang secara berkelanjutan karena adanya produser sebagai penyandang dana produksi seni pertunjukan tersebut. 


\section{Ideologi Pasar}

Sebagaimana telah diuraikan bahwa suatu seni pertunjukan mampu berkembang secara berkelanjutan karena kuatnya pengaruh dari luar dan dalam. Lull (1998) menyatakan bahwa salah satu dimensi globalisasi adalah mengalirnya ideologi dari negara maju ke negara-negara yang sedang berkembang. Salah satu bentuk ideologi dimaksud adalah ideologi pasar. Maguire (2004) menyebut hal tersebut sebagai agama pasar. Hal itu wajar karena pasar mampu menggiring kearah kemakmuran dan kesejahteraan dengan tangannya yang tidak kelihatan (invisible hands)" (Sumardi, 1982).

Ideologi pasar dapat dengan cepat mempengaruhi bentuk maupun keberlanjutan suatu produk. Perkembangan ilmu pengertahuan yang dikuasai oleh negara-negara maju, bukan negara-negara berkembang seperti Indonesia mampu menggerakkan komunikasi. Akibatnya, negara-negara berkembang seperti Indonesia khawatir akan tertinggal dalam kemajuan arus globalisai dalam bidang politik, ekonomi, sosial, dan budaya. Tekanan dari luar seperti tumbuhnya kesenian-kesenian modern yang inovatif dan melibatkan teknologi-teknologi canggih didalamnya membuat seni pertunjukan tersebut terlihat lebih megah dan menakjubkan. Di sisi lain kebanyakan seni pertunjukan tradisional tidak dapat bersaing dengan seni-seni pertunjukan yang modern. Sebagaimana halnya Cak Bedulu yang tidak dapat menjaga eksistensinya dalam mengisi keinginan pasar atau penonton.

Penonton selaku konsumen tentu ingin memperoleh pertunjukan sesuai dengan harapannya baik dari segi bentuk atau kualitas, harga yang lebih murah. Selain itu penonton selaku konsumen menginginkan dapat menonton pertunjukan yang diinginkan gampang atau mudah diperoleh atau ditonton. Artinya ketika mereka menginginkan untuk menonton Cak Bedulu tidak harus datang ke Desa Bedulu yang jaraknya jauh, waktu pementasan tidak sering, lokasi yang mudah dijangkau. Selain faktor tersebut diatas unsur pendistribusian produk atau seni pertunjukan Cak Bedulu mesti mampu mendistribusikan atau memasarkan pertunjukan itu. Promosi Cak Bedulu berdasarkan kualitas pertunjukan memang tampak telah terpenuhi. Namun demikian pendistribusian Cak Bedulu melalui media cetak maupun elektronik keliatannya masih jauh dari harapan. Jika penoton selaku konsumen ingin memperoleh atau menonton pertunjukan Cak Bedulu harus mengeluarkan uang lebih banyak jika dibandingkan dengan ketika mereka menonton vidio, film yang lebih mudah dan murah untuk dilakukan.

Maraknya seni media elektronik mau tidak mau, harus dihadapinya dengan jalan meningkatkan daya kreativitas dan melakukan inovasi lainnya sesuai tuntutan jaman, realitas ini sesuai dengan pendapat Piliang (1999) bahwa budaya lokal dalam era globalisasi ekonomi, informasi, dan kultural dewasa ini berada dalam sebuah kondisi tar- ik-menarik. Upaya-upaya menciptakan keungulan lokal (local genius) dapat dilihat sebagai sebuah strategi agar budaya lokal dapat mengaktualisasikan dirinya dalam konteks global dan dipihak lain menghindarkan berbagai pengaruh homogenisasi budaya. Untuk itu penggalian keunggulan lokal memerlukan berbagai pemikiran-pemikiran baik pada tingkat filosofis, ekonomis, sosiologis, dan kultural sehingga diharapkan dapat membuka peluang bagi pengayaan budaya lokal, dengan menciptakan ruang bagi pengembangan kreativitas lokal atau inovasi kultural, tanpa harus mengorbankan nilai-nilai dasarnya. Tingginya pengaruh teknologi informasi tampak telah menyebabkan Cak Bedulu terpuruk akibat pengaruh seperti televisi yang menyodorkan berbagai hiburan. Teknologi seperti televisi dan lain-lainya secara tidak langsung telah mengintegrasikan ekonomi lokal, nasional berdasarkan dominasi promosi dan strategi pendekatan culture masing-masing penonton.

\section{Selera Pasar}

Perkembangan pariwisata di Bali dewasa ini, mampu memancing kreativitas para seniman untuk menciptakan kesenian baru yang lebih atraktif dan menghibur para wisatawan. Para pelaku seni tradisional yang mampu memanfaatkan dengan baik fenomena globalisasi dengan cara menautkan aktivitas berkesenian dengan dunia global tidak jarang memperoleh keuntungan yang luar biasa. Para seniman bisa menjadi terkenal sekaligus menerima pemasukan finansial yang tidak sedikit. Hal tersebut mengindikasikan bahwa kesenian tradisional juga masih laku untuk dijual, walaupun harus dimodifikasi agar sesuai dengan selera masyarakatdan wisatawan jaman sekarang.

Memodifikasi kesenian tradisional agar sesuai dengan selera masyarakat dan wisatawan kiranya bukan lagi hal yang tabu. Hampir sebagian besar jenis kesenian di Bali khususnya sebenarnya merupakan hasil penyesuaian-penyesuaian atau hasil kompromi dengan perkembangan jaman. Kesenian tradisional yang tidak mampu berkompromi dengan perkembangan jaman maka dengan sendirinya akan berangsur-angsur surut dan akhirnya akan punah. Hal tersebut terkait erat dengan sifat manusia yang selalu menginginkan hal-hal yang baru. Kesenian Cak Bedulu misalnya, kesenian ini masih mempertahankan pakem dasar warisan leluhur terdahulu. Tidak ada perubahan dari segi bentuk dan struktur pementasannya. Tidak ada modifikasi dari segi gerak dan vokal yang menjadi ciri khas pertunjukan Cak. Dahulu Cak Bedulu merupakan salah satu pertunjukan yang digemari oleh para wisatawan. Tetapi ketidakmampuan kesenian ini untuk mengadaptasi budaya global dan memenuhi selera penonton membuatnya semakin ditinggalkan. Bahkan masyarakat pelaku juga enggan untuk berkecimpung dalam pementasan Cak Bedulu.

Cak Bedulu sebagai seni pertunjukan tradisional telah ditinggalkan masyarakanya. Pertunjukan yang monoton dan masih benar-benar original sudah tidak terlalu dilir- 
ik lagi oleh para wisatawan dewasa ini. Para wisatawan maupun masyarakat penikmat seni membutuhkan suguhan yang lebih fresh dan inovatif. Agar kesenian Cak Bedulu mencapai eksistensinya kembali di tengah-tengah arus perubahan yang radikal dan cepat, maka para seniman pendukung dan tokoh-tokoh seni di Desa Bedulu dituntut mampu memberikan ide-ide baru dan memanfaatkan perkembangan teknologi modern. Memanfaatkan perangkat teknologi modern merupakan salah satu cara untuk meningkatkan nilai jual kesenian tradisional. Mempelajari berbagai kejadian kontemporer yang berkembang dimasyarakat juga menjadi modal utama agar kesenian tradisional yang mereka dukung tidak stagnan atau jalan di tempat. Di sisi yang lain, seniman-seniman yang mampu mempertautkan aktivitas kesenian mereka dengan dunia luar juga turut andil dalam memperkuat eksistensi kesenian tradisional. Masih banyak wisatawan yang tertarik dengan kesenian tradisional kita karena dianggap unik dan artistik. Banyak orang-orang dari luar negeri ingin belajar kesenian tradisional dan mengkaji kesenian tersebut karena pada awalnya mereka melihat informasi kesenian itu dari internet. Seniman tradisional harus memanfaatkan media-media elektronik untuk mempromosikan jenis kesenian tradisional yang mereka geluti. Keterlibatan pemerintah dalam rangka mempromosikan kesenian tradisional mutlak diperlukan.

\section{Ideologi Estetika}

Gagasan untuk menciptakan sebuah seni pertunjukan pada dasarnya adalah untuk memenuhi berbagai macam kebutuhan. Seperti yang dikemukakan oleh Soedarsono (1998) bahwa kemplok masyarakat membentuk kesenian dengan tujuan yang berbeda-beda seperti untuk kepentingan ritual, seni pertunjukan untuk mengungkapkan rasa estetik dan untuk sarana hiburan. Dengan adanya kepentingan yang berbeda-beda itu muncullah berbagai macam kesenian dalam suatu kelompok masyarakat.

Sedyawati (1981) menguraikan kesenian menurut fungsinya dibagi menjadi tujuh yaitu untuk memangil kekutan gaib, mengundang roh agar hadir ditempat pemujaan, menjemput roh-roh baik, peringatan kepada nenek moyang, mengiringi upacara perputaran waktu, mengiringi upacara siklus hidup, dan untuk mengungkapkan keindahan alam semesta. Sementara itu Alan P. Merriam yang dikutip oleh Soedarsono (1998) merumuskan bahwa ada sepuluh fungsi seni dalam kehidupan masyarakat, yaitu sebagai ekspresi emosional, kenikmatan estetis, sebagai hiburan, sebagai alat komunikasi, sebagai persembahan simbolik, sebagai respon fisik untuk menjaga norma dalam masyarakat untuk pengukuhan institusi dan ritual sebagai stabilitas kebudayaan dan sebagai sarana integritas masyarakat.

Selain itu seni sangat erat berhubungan dengan keadaan masyarakat dan budaya setempat. Oleh karena itu fungsi peranan dan jenis-jenisnyapun sangat berhubungan dengan masyarakat dan budaya setempat. Bahkan dalam perkembangannya seni pertunjukan dipengaruhi oleh masyarakat dan budayanya. Seperti yang diungkapkan oleh Bandem (1996) bahwa dalam kehidupan masyarakat Bali kesenian mempunyai tiga fungsi yakni wali, bebali, dan balih-balihan. Tari wali adalah sebuah tarian yang dilaksanakan pada saat upacara keagamaan di suatu pura. Tari wali atau sakral ini umumnya dipentaskan di halaman tengah pura (jeroan/purian). Jenis yang termasuk tarian wali yaitu tari Pendet dan tari Sanghyang. Tari Bebali adalah tarian yang dipentaskan dalam upacara keagamaan dan umumnya tari bebali dipentaskan dengan suatu lakon yang berhubungan dengan pelaksanaan upacara tersebut seperti tari Topeng dan Gambuh. Tari balih-balihan merupakan perkembangan dari seni wali dan bebali yang ditunjukankan sebagai sarana hiburan dengan lakon serta kreasi tari dan tabuh yang lebih bebas. Seringkali jenis tarian ini mengunakan lakon-lakon yang popular di kalangan masyarakat. Jenis tarian yang termasuk tari balih-balihan yaitu tari Legong dan Cak. Tarian tersebut pada awalnya merupakan tarian sakral dan persembahan.

Pesatnya perkembangan pariwisata menyebabkan banyak tarian-tarian tradisional beralih fungsi dari awalnya sebuah seni pertunjukan sakral kini beralih funsi menjadi pertunjukan pariwisata. Bentuk seni pertunjukan pariwisata merupakan akulturasi dari estetika seni pertunjukan tradisional daerah setempat dengan kebutuhan dan selera wisatawan. Penggabungan kebutuhan dan selera wisatawan dengan estetika seni pertunjukan daerah setempat melahirkan sebuah bentuk pertunjukan pariwisata yang bernuansa nilai ekonomi. Semakin sesuai bentuk penyajiannya, nilai dari seni pertunjukan daerah yang dikemas menjadi sebuah produk pariwisata itu akan memiliki nilai jual semakin tinggi. Oleh sebab itu dalam penyajiannya, para pelaku pariwisata termasuk para kreator dan senimannya mesti memperhatikan konteks, ruang, dan waktu penyajian yang diinginkan wisatawan. Ruastiti (2010) mengatakan bahwa selain menyesuaikan dengan kebutuhan pariwisata, seni pertunjukan tradisional yang disajikan untuk pariwisata haruslah disesuaikan dengan konsep tata ruang arsitektur tempat pementasan.

\section{BENTUK PERTUNJUKAN CAK BEDULU}

Bentuk adalah wujud fisik yang dapat diamati sebagai media untuk menuangkan isi yang berisi nilai-nilai dan memberikan pengalaman tertentu (Humardani, 1979:49-50). Duccase dalam The Liang Gie (1996:33-34) menyatakan bahwa bentuk tersusun atas unsur-unsur abstraksi seperti ragam gerak, struktur pertunjukan, iringan musik, dan tempat pertunjukan. Sejalan dengan ungkapan pemikiran Humardani dan Duccase bahwa Cak Bedulu merupakan ungkapan unsur-unsur penari, dialog, tata rias, busana, dan musik pengiringnya, gerak bernilai yang tersusun dalam bentuk yang bisa disimak dan memberikan pengalaman 
keindahan bagi para pelaku dan penonton pertunjukan.

Pertunjukan Cak Bedulu digarap dalam bentuk kolosal. Hal itu dapat diamati dari jumlah penari yang terlibat di setiap pementasannya dalam konteks pariwisata. Cak Bedulu memiliki komposisi besar berdasarkan atas bentuk (form) dan struktur (structure). Kata "wujud" sendiri mempunyai arti lebih luas apabila di bandingkan dengan kata "rupa" yang lazim dipakai dalam kata "seni rupa" (Djelantik, 2008).

Cak Bedulu merupakan sebuah dramatari musikal dimana pertunjukan ini diiringi oleh vokal penarinya yang terinspirasi dari pertunjukan sakral sanghyang. Cak Bedulu dijadikan sebagai pertunjukan wisata pertama kali di objek pariwisata Goa Gajah. Elemen-elemen yang membangun pertunjukan tersebut saling terkait dan tidak dapat dipisahkan satu sama lain antara gerak, penari, tata rias dan busana, iringan musik, tempat pementasan dan lain sebagainya. Dalam kaitannya dengan Cak Bedulu, pertunjukan tersebut dibangun oleh dua unsur, yakni unsur yang dapat dilihat oleh mata dan unsur yang tidak dapat dilihat oleh mata. Unsur yang dapat dilihat oleh mata antara lain, seperti: ragam gerak, tata rias dan busana, properti, tata lampu dan tempat pementasan yang dipergunakan. Sementara, unsur yang tidak dapat dilihat oleh mata pada pertunjukan Cak Bedulu adalah musik iringan yang indah mengiringi pertunjukan tersebut dan suasana pentas yang menggugah emosi penonton. Dengan demikian wujud dapat dilihat dengan mata (visual) maupun dapat di dengar oleh telinga. Wujud dapat dianalisis dengan komponen-komponen yang menyusunnya serta dari segi susunannya itu sendiri. Djelantik (2008) menjelaskan bahwa keindahan kesenian disimak atas kepemilikan bentuk dengan penampilan (presentation) beserta wujud atau rupa dan bobot atau isi (conten, subtancet). Isi atau bobot adalah benda atau peristiwa kesenian meliputi bukan hanya dilihat semata-mata tetapi juga apa yang dirasakan atau dihayati sebagi makna dari wujud kesenian itu. Bobot kesenian mempunyai tiga aspek, yaitu: suasana (mood), gagasan (idea), dan pesan. Penampilan adalah cara kesenian tersebut disajikan. Penampilan terdiri dari tiga aspek, yaitu: bakat (talent), keterampilan (skill), dan sarana atau media (medium atau vehicle). Semua itu terkonsep yang mendasari susunan struktur beserta unsur penyusun bentuk (form).

Sebagai sarana komunikasi, seni pertunjukan memiliki peranan yang penting dalam kehidupan masyarakat. Pada berbagai acara seni pertunjukan dapat berfungsi menurut kepentingannya. Masyarakat membutuhkan seni pertunjukan bukan saja sebagai kepuasan estetis, melainkan dibutuhkan juga sebagai sarana upacara Agama dan Adat. Berbeda dengan pertunjukan Cak Bedulu berfungsi tidak hanya sebagai kepuasan estetis melainkan untuk kepentingan pariwisata.
Gerak dalam Cak Bedulu merupakan ungkapan keinginan yang digerakan sebagai pernyataan komunikasi gagasan dari koreografernya. Dapat pula berarti sebagai ungkapan ekspresi perasaan pelaku yang diimplementasikan secara imajinatif berdasarkan peluang dan kondisi lingkungan, sehingga ragam gerak pada pertunjukan menjadi wujud gerakan simbolis yang tidak saja menyimpan pesan dari para pelaku, utamanya koreografer. Namun pula menciptakan suasana atau tema dalam Pertunjukan Cak Bedulu yang menarik bagi para penonton. Sebagaimana bisa dilihat pada foto berikut:

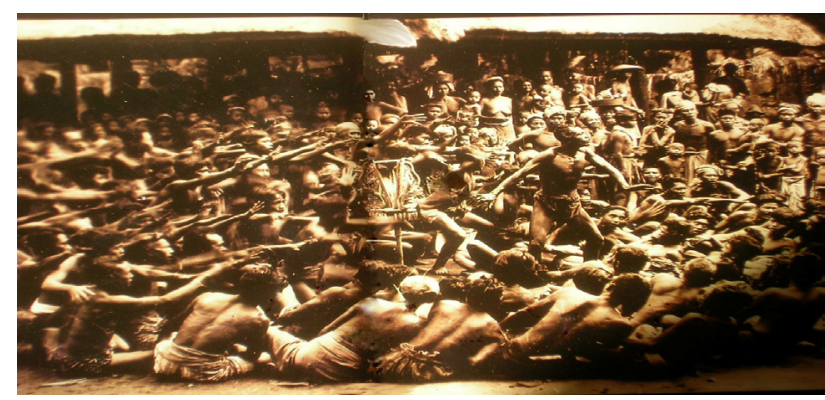

Gambar 1. Pementasan Cak Bedulu tahun 1920an (Dokumentasi: Pekak Agung Putra, Desa Bona)

Foto di atas menunjukkan adegan dag (pemimpin koor) Cak Bedulu berimprovisasi dan berinteraksi dengan penari cak. Cak Bedulu yang digagas oleh Walter Spies dan I Wayan Limbak tergolong kedalam bentuk dramatari musikal melibatkan percakapan atau dialog tentang ajaran kehidupan yang memberikan bobot bagi penampilan dari puluhan penari yang hanya menggunakan iringan musik dari vokal atau suara penarinya. Tidak terlihat adanya perubahan secara signifikan sehingga originalitas dari pertunjukan Cak Bedulu masih terjaga dengan baik. Dengan meningkatnya kunjungan wisatawan ke Bali menyebabkan banyak seni pertunjukan sejenis yang bermunculan. Hal ini berdampak terhadap eksistensi pementasan Cak Bedulu. Sekarang sudah banyak terdapat sekaa Cak di Bali sehingga banyak pilihan. Cak Bedulu dulunya sangat diminati dan ramai disaksikan oleh tamu mancanegara karena merupakan pertunjukan cak pertama yang ada di Gianyar. Semakin kedepan Cak Bedulu kalah bersaing dengan cakcak lainnya yang lebih modern dan dapat memenuhi selera wisatawan..."

Beberapa unsur-unsur tradisi budaya yang terdapat di dalam pertunjukan Cak Bedulu, seperti lakon, gerak dan busananya sudah tidak sesuai dengan selera wisatawan, sehingga pertunjukan Cak Bedulu ditinggalkan oleh wisatawan. Pertunjukan Cak Bedulu tidak eksis lagi di dunia pariwisata. Para wisatawan cenderung tertarik engan pertunjukan bernuansa bernuansa baru yang mampu menampilkan sebuah sajian pariwisata yang inovatif dan variatif. 


\section{Struktur Pertunjukan Cak Bedulu}

Kata struktur mengandung arti susunan, yang jika dikaitkan dengan seni tari dapat diartikan sebagi sebuah susunan dari bagian-bagian yang saling terkait. Dalam hal ini, Cak Bedulu memiliki struktur pertunjukan yang dibentuk oleh ragam gerak dirangkai menjadi sebuah pertunjukan tari, dibalut busana yang khas serta diiringi oleh musik dari vokal penarinya sehingga menjadi sebuah satu kesatuan tari.

Sebagai media untuk berkomunikasi dengan penonton, penari menggunakan gerak sebagai unsur pokok pertunjukan. Gerak memiliki peranan besar dalam tari. Gerakan itu dirangkai, ditata, dan disatukan ditunjang unsur-unsur lainnya seperti tata rias busana, dan iringan musik maka terciptalah sebuah tarian. Demikian pula halnya dengan pertunjukan Cak Bedulu yang dibangun oleh berbagai jenis gerakan dengan struktur pertunjukan sebagai berikut.

Babak pertama ini diawali dengan keluarnya seorang penari yang berperan sebagai Subali sambil melantunkan tembang berbahasa kawi. Selanjutnya karakter Subali memanggil bala tentara kera yang dimana diperankan oleh penari cak lain yang berjumlah 50-100 orang. Penari cak keluar dengan gerakan mengangkat kedua tangan keatas dan melantunkan suara "wuuuuuss....wuuusssss" yang diartikan sebagai suara angin. Penari keluar secara bersamaan dan membentuk lingkaran. Setelah penari cak duduk melingkar kemudian para penari melakukan gerakan goyod, gerakan mengangkat tangan ke atas dan menyamping sembari melantunkan koor "Caaakkk", "Cuuukkk" yang jika dilantukan bersama-sama akan menghasilkan kekilitan cak. Rangkaian gerak dan koor akan dikomandoi oleh seorang dag atau pemimpin koor pada pertunjukan cak.

Babak kedua dari pertunjukan Cak Bedulu menceritakan dua raksasa bernama Mahesasura dan Lembusura. Kedua raksasa ini memiliki kesaktian yang luar biasa sehingga membuat para dewa takut. Lalu Bhatara Guru mengutus dua kesatria kera yaitu Subali dan Sugriwa untuk melawan kedua raksasa tersebut. Dua raksasa ini diperankan oleh dua orang penari nantinya kedua penari raksasa ini akan memberikan komando kepada penari cak lain. Penari cak saling bersahutan antara satu dengan yang lain. Penari cak digambarkan sebagai bala tentara raksasa.

Babak ketiga menceritakan adegan Subali dan Sugriwa bercengkrama untuk melaksanakan tugas dari Bhatara Guru serta bersiap-siap untuk berperang melawan raksasa Mahesasura dan Lembusura. Subali dan Sugriwa diperankan oleh dua orang penari dengan karakter layaknya seekor kera. Disini para penari cak berperan sebagai tentara kera. Penari cak melantunkan koor "cak...cak... cak" dan melakukan gerakan ngoyod serta sesekali gerakan mengangkat tangan ke atas untuk mengiringi adegan Subali dan Sugriwa. Gerakan seperti itu menggambarkan riuh dan semangat tentara kera untuk berperang melawan pasukan raksasa.

Babak keempat memperlihatkan adegan Dewi Tara yang sedang menunggu suaminya yaitu Subali yang sedang berperang melawan raksasa Mahesasura dan Lembusura. Sugriwa yang tidak lain adalah saudara kembar Subali datang dan mengabarkan Subali telah kalah melawan kedua raksasa itu. Pada adegan ini Dewi Tara yang diperankan oleh seorang penari perempuan menari dengan lemah gemulai di tengah-tengah lingkaran penari cak. Para penari cak melantunkan koor "cak...cak...cak" dengan tempo yang lambat dan diiringi melodi tatembangan yang dilantunkan oleh beberapa penari cak.

Cak Bedulu menceritakan tentang adegan Subali yang datang dari medan perang dan melihat Sugriwa dan Dewi Tara sedang memadu kasih. Subali marah kepada Sugriwa karena Sugriwa telah mengkhianati Subali. Akhirnya terjadilah perang saudara antara Subali dan Sugriwa. Para penari cak kembali menaikkan tempo lantunan koor "cak... cak...cak". Bisa dilihat bagaimana penggambaran suasana dari tempo lantunan koor dari para penari cak. Setelah adegan Sugriwa kalah melawan Subali, para penari cak membagi posisi menjadi dua kelompok yaitu di sisi kanan panggung dan kiri panggung. Para penari melakukan gerakan saling bersahutan, dimana jika penari cak di sisi kanan melakukan gerakan berdiri maka penari di sisi kiri akan merebahkan badannya begitu juga sebaliknya.

Cak Bedulu pertama kali di pentaskan di Pura Goa Gajah, yaitu di depan goa peninggalan sejarah yang menjadi objek pariwisata yang sering di kunjungi oleh wisatawan. Tempat pementasan di Goa Gajah termasuk ke dalam kategori panggung terbuka. Selain Pura Goa Gajah, Cak Bedulu juga sempat dipentaskan secara regular di stage Pura Samuan Tiga. Tempat pementasan Cak Bedulu di Pura Goa Gajah dan Stage Pura Samuan Tiga tidak dilengkapi dengan pengunaan pencahayaan modern mengingat pementasan Cak Bedulu hanya menggunakan pencahayaan dari lampu minyak tanah yang biasa disebut penyembean. Penyembean adalah ciri khas dari pementasan cak dan biasanya diletakkan di tengah-tengah panggung. Pementasan Cak Bedulu biasanya dilakukan pada saat senja atau malam hari. Dengan hanya menggunakan cahaya api membuat pertunjukan cak terasa magis. Semakin kedepan perkembangan teknologi semakin maju. Banyak pertunjukan mulai mengaplikasikan pencahayaan modern untuk mendukung pementasannya. Bahkan pertunjukan Cak yang dulunya hanya menggunakan pencahayaan sederhana dari api sekarang mulai banyak yang menggunakan bantuan pencahayaan modern untuk mendukung suasana dari setiap adegan yang ditampilkan. Lampu yang biasanya digunakan salah satunya adalah hologen dan follow light. Contohnya penggunaan lampu saat adegan perang digunakan lampu berwarna merah agar mempertegas suasana dari adegan perang tersebut. Lebih jauh lagi dalam 
penggunaan teknologi, adegan-adegan cak juga didukung dengan smoke mechine atau mesin asap yang mengeluarkan asap untuk menguatkan suasana-suasana tertentu. Penggunaan teknologi diatas penting untuk meningkatkan kualitas dari sebuah pertunjukan. Hal ini yang tidak diaplikasikan ke dalam Cak Bedulu yang masih mempertahankan pakem tradisi. Dampaknya penonton lebih berhasrat untuk menyaksikan pertunjukan bernuansa baru yang lebih terlihat menarik dan inovatif.

\section{IMPLIKASI KETERPINGGIRAN CAK BEDULU}

Pada awalnya seni di Bali khususnya seni tari digunakan sebagai pelengkap sebuah upacara keagamaan, namun seiring berkembangnya pariwisata seni difungsikan diberbagai aspek kehidupan masyarakat Bali, dengan demikian fungsi seni tari semakin berkembang dengan pesat. Seni yang awalnya bersifat sakral kini dimodifikasi menjadi sebuah pertunjukan konfensional yang dalam pengemasannya dimasukkan unsur teknologi, sehingga seni tari yang awalnya terlihat sederhana kini berubah menjadi sebuah seni pertunjukan yang modern dan inovatif.

Masyarakat pada umumnya mulai tertarik akan hal-hal yang bersifat modern sehingga lebih menyukai sebuah pertunjukan yang bersifat menghibur. Bagi masyarakat di era global ini seni yang bersifat tradisional sudah ketinggalan jaman, sehingga mereka lebih berlomba-lomba untuk mempelajari sebuah seni pertunjukan yang memiliki nilai jual tinggi dan bersifat ekonomis. Dengan demikian seni tradisional mulai mengalami keterpinggiran.

Dewasa ini lebih banyak berkembang seni pertunjukan yang dipertontonkan untuk pariwista, dengan demikian tidak menutup kemungkinan kesenian tradisional akan kehilangan eksistensinya. Keadaan ini menyebabkan seni pertunjukan Bali mengalami perkembangan dari segi pertunjukan yang dipertontonkan untuk pariwisata, namun implikasi dari hal tersebut seni di Bali mulai kehilangan beraneka ragam jenis-jenis seni pertunjukan.

Pada awalnya Cak Bedulu merupakan sebuah pertunjukan yang kaya akan nilai-nilai dan moral dalam kehidupan bermasyarakat. Seni pertunjukan Cak di Bedulu sempat menjadi hiburan masyarakat yang kemudian berkembang menjadi seni pertunjukan pariwisata. Aktivitas seni Cak Bedulu bahkan sempat menjadi identitas desa tersebut. Pada saat mengalami masa jayanya, sekaa Cak Bedulu mempunyai jadwal pentas yang sangat padat. Demikian pula kunjungan pariwisata ke daerah itu sangat ramai.

Belakangan ini kesenian Cak Bedulu yang telah mengisi dinamika kehidupan masyarakat Desa Bedulu kian marginal. Pencapaian estetik yang pernah diraihnya semakin memudar dan fungsi-fungsi sosial yang sempat diisinya mulai kurang dapat perhatian. Begitupula makna-makna kultural yang pernah mengawalnya semakin menjauh, bahkan kesenjangan Cak Bedulu dengan generasi muda semakin lebar. Generasi muda saat ini semakin tidak peduli terhadap keberadaan Cak Bedulu. Orientasi masyarakat di tengah gelombang globalisasi yang cenderung lebih berpikir terhadap suatu hal yang bernilai ekonomi dan materialistis membuat pertunjukan Cak Bedulu ini semakin terpinggir.

\section{SIMPULAN}

Berdasarkan uraian di atas dapat disimpulkan bahwa Cak Bedulu mengalami keterpinggiran disebabkan karena penyajian seni pertunjukan itu sudah tidak sesuai lagi dengan ideologi pasar masa kini, ideologi estetika seni pertunjukan pariwisata, dan ideologi budaya masyarakat setempat saat ini. Masyarakat Desa Bedulu yang sudah tergolong maju dan modern kini telah berpikir kritis. Mereka tampak memprioritaskan waktunya untuk memenuhi kebutuhan hidupnya melalui sektor pekerjaan di industri pariwisata, pengrajin, pengusaha, dagang, PNS, dan lain sebagainya. Kemajuan teknologi yang secara tidak langsung mempengaruhi keberadaan seni untuk pariwisata membutuhkan inovasi terabaikan. Sebuah seni pertunjukan pariwisata yang tidak memiliki pemasaran yang baik sulit bersaing dengan kelompok-kelompok seni pertunjukan pariwisata lainnya di masa sekarang yang telah memanfaatkan sosial media elektronik sebagi cara pemasarannya. Cak Bedulu berdasarkan kualitas pertunjukan memang tampak telah terpenuhi. Namun demikian pendistribusiannya melalui media cetak maupun elektronik tampak masih jauh dari harapan. Sehingga hal ini berdampak terhadap eksistensi pertunjukan Cak Bedulu.

Keterpinggiran Cak Bedulu melalui beberapa tahapan, antara lain diawali kurangnya pemasaran dan menurunnya minat wisatawan menonton pertunjukan Cak Bedulu. Perkembangan pariwisata menyebakan banyaknya muncul pertunjukan pariwisata yang lebih modern. Hal tersebut menjadi alternatif pilihan hiburan yang lebih beragam bagi para wisatawan dibanding pertunjukan tradisional. Akibatnya wisatawan tidak begitu tertarik lagi menikmati seni pertunjukan tradisional seperti Cak Bedulu dan kurangnya pemasaran juga berakibat tidak banyak agen dan wisatawan mengetahui keberadaan Cak Bedulu. Selain itu kurangnya masukan finansial bagi para pihak terkait hal ini disebabkan sepinya permintaan pasar. Serta menurunnya minat masyarakat menjadi pelaku pertunjukan Cak Bedulu merupakan proses marginalnya pertunjukan tersebut. Penurunan sebuah seni tradisional tentu ada kaitannya dengan regenerasi yang tidak berkesinambungan. Generasi muda lebih tertarik terhadap hal yang bersifat modern seperti game, media sosial, dan televisi sehingga sebuah kesenian tradisi mulai ditingalkan oleh generasi muda karena dianggap sudah tidak sesuai lagi dengan gaya hidup masa kini. Dan yang terakhir Bubarnya sekaa sehingga 
Cak Bedulu tidak dapat dipentaskan kembali.

Keterpinggiran Cak Bedulu berimplikasi pada hilangnya media berkesenian masyarakat. Menurunnya masukan finansial masyarakat dari kegiatan berkesenian dan hilangnya Cak Bedulu sebagai identitas budaya lokal ditengah lajunya transformasi budaya keberadaan seni tradisi semakin meredup. Hal ini menyebabkan menurunnya nilai-nilai tradisi yang ada pada masyarakat.

\section{DAFTAR PUSTAKA}

Bandem, I Made. 1996. Etnologi Tari Bali. Denpasar: Kanisius.

Bennet, G.K., et.al. 1952. Differential Aptitude Test Manual. 2 nd edition. New. York: The Psychological Corporation.

Benny H. Hoed, 2011. Semiotik \& Dinamika Sosial Budaya. Cetakan Pertama, Beji Timur, Depok.

Djelantik, Sukawarsini. 2008. Diplomasi antara Teori dan Praktik. Bandung : Graha Ilmu.

Humardani, 1979. Kreativitas Dalam Kesenian. Surakarta: Depdikbud.

Kodiran. 1999. "Kebudayaan Jawa”. Manusia dan Kebudayaan (Koentjaraningrat Editor). Jakarta : Djambatan.

Koentjaraningrat. 1987. Sejarah Teori Antropologi I. Jakarta: Universitas Indonesia.

Kusumastuti, Adhi. 1990. Psikologi Suatu Pengantar. Yogyakarta : Balai Penerbit.

Liliweri, Alo. 2002. Makna Budaya Dalam Komunikasi Antar Budaya. Jogyakarta: LKiS.

Lull, James. 1998. Media Komunikasi Kebudayaan. Jakarta : Yayasan Obor Indonesia.

Maguire, I. 2004. Hylocereus Polyrhizus. Home Page Online. Available From http://trec.ifas.ufl. edu./tfphoto/10-01-04.html

Munandar, Utami. 1987. Mengembangkan Bakat dan Kreativitas Anak Sekolah : Penuntun Bagi Guru dan Orang Tua. Jakarta : Gramedia.

Noris, C. 2003. Membongkar Teori Dekontruksi Jacques Derrida. Yogyakarta: Ar-Ruzz.

Piliang, Yasraf. 1999. Hiper-realitas Kebudayaan : Semiotika, Estetika, Posmodernisme. Bandung:LKIS.
Ruastiti, Ni Made. 2005. Seni Pertunjukan Bali Dalam Kemasan Pariwisata. Denpasar: Bali Mangsi Press.

Ruastiti, Ni Made. 2010. Seni Pertunjukan Pariwisata Bali. Yogyakarta: Kanisius

Sedyawati, Edy. 1981. Pertumbuhan Seni Pertunjukan. Sinar Harapan: Jakarta

Soedarsono. 2002. Seni Pertunjukan Indonesia di Era Globalisasi. Yogyakarta: Gadjah Mada University press

Spillane J.J. 1987. Pariwisata Indonesia Sejarah dan Prospeknya. Yogyakarta : Kanisius.

Suganda. 2002. Manajemen Seni Pertunjukan. Bandung: STSI Press.

Sumardi, Mulyanto dan Dieter-Evers, Hans. (1982). Kemiskinan dan Kebutuhan Pokok. Jakarta : Rajawali.

Sumardjo, Jakob. 2000. Filsafat Seni. Bandung : Penerbit ITB.

Sunaryo. 2004. Psikologi Untuk Pendidikan. Jakarta: EGC.

The Liang Gie. 1996. Filsafat Seni. Sebuah Pengantar. Yogyakarta: PUBIB. 